\title{
Antagonistic Effect of Pseudomonas fluorescens on the Mycelial Growth and the Viability of the Sclerotia of Rhizoctonia solani in vitro and in Soil
}

\author{
Y. Sandhya ${ }^{1 *}$, C. P. D. Rajan ${ }^{2}$ and M. Reddikumar ${ }^{1}$ \\ ${ }^{1}$ Department of Plant Pathology, S.V. Agricultural College, Tirupati (517502), A.P., India \\ ${ }^{2}$ Regional Agricultural Research Station, Nellore (524003), A.P., India \\ *Corresponding author
}

\section{A B S T R A C T}

Pseudomonas fluorescens isolates NLR-B1, NLR-B2, NLR-B3 were tested in dual culture against $R$. solani among which NLR-B3 isolate was found to be more antagonistic in vitro against Rhizoctonia solani than other two isolates. Sclerotial germination was tested after

\begin{tabular}{|l|}
\hline Key w ord s \\
Pseudomonas \\
fluorescens, \\
Rhizoctonia solani, \\
Sclerotia, dual culture \\
\hline Article Info \\
\hline Accepted: \\
22 May 2018 \\
Available Online: \\
10 June 2018 \\
\hline \hline
\end{tabular}
incubating in NLR-B3 bacterial suspension in the concentrations from $10^{-4}$ to $10^{-8} \mathrm{CFU} / \mathrm{ml}$, there was no inhibition in sclerotial germination at $10 \mathrm{~min}$ incubation at all concentrations of bacterial suspension, whereas at 20 min incubation, inhibition of sclerotial germination was 73.33 per cent at $10^{-4}$ concentration, 43.33 per cent at $10^{-5}$ concentration, 30 per cent at $10^{-6}$ concentration and there was no inhibition of sclerotial germination at $10^{-7}$ and $10^{-8}$ concentrations. At the incubation period of $30 \mathrm{~min}$. inhibition in sclerotial germination was 53.33 per cent at $10^{-4}$ concentration, 36.67 percent at $10^{-5}$ concentration, 30 per cent at $10^{-6}$ concentration. Similar inhibition of 13.33 percent was observed both at $10^{-7}$ and at $10^{-8}$ concentration. Per cent inhibition increased with increase in concentration of bacterial suspension at 20 and 30 min incubation periods. The bacterial suspensions at the earlier concentrations were added to the soil and incubated for 10 days after which the sclerotia were retrieved and tested for their viability, the inhibition of sclerotial germination was 56.67 per cent at $10^{-4}$ concentration, 36.66 per cent at $10^{-5}$ concentration and 16.66 per cent at $10^{-6}$ concentration. However at lower concentration of $10^{-7}$ and $10^{-8}$ there was no inhibition of sclerotial germination. There was a significant increase in per cent inhibition of sclerotial germination with increase in concentration of the bacterial suspension.

\section{Introduction}

Rice (Oryza sativa L.) is one of the most important cereal crops grown all over the world with a production of 550 million tonnes. In India, rice is grown over an area of 43.95 million hectares with production of 106.54 million tonnes and $2424 \mathrm{~kg}$ per hectare productivity. Rice is affected by several fungal, bacterial and viral diseases. As many as thirty five fungal, eight bacterial and twenty viral and mycoplasmal diseases were reported on rice $(\mathrm{Ou}, 1985)$. Of these rice sheath blight is second only to, and often rivals rice blast in importance. Rice Sheath blight is caused by Rhizoctonia solani Kuhn. The symptoms of the disease, usually appear as spots on the sheaths near the water line. The spots are first ellipsoid or ovoid, somewhat irregular, greenish grey, varying from 1 to $3 \mathrm{~cm}$ long. 
These spots or lesions coalesce and advance from the leaf sheaths to the leaf blades. The presence of several large lesions upon a leaf sheath usually causes the death of the whole leaf and all the leaves may be blighted in severe cases. The fungus produces brown sclerotia depending upon environmental conditions. (Ou, 1985). The sclerotia survive for long periods and tend to accumulate in the soil (Lee and Rush, 1983). Therefore, the sclerotia of $R$. solani play an important role in the pathogen survival in rice fields. It has been reported that sclerotial viability in paddy soil is affected by soil microorganisms, making biological control an attractive alternative strategy for controlling rice sheath blight (Vasantha Devi et al., 1989).

\section{Materials and Methods}

\section{Isolation of Pathogen}

The causal organism $R$. solani Kuhn was isolated from rice plants showing typical sheath blight symptoms under field conditions. Leaf sheath showing typical symptoms was washed in tap water for few minutes and leaf bits of 3-8 $\mathrm{mm}$ size were surface sterilized with $1 \%$ sodium hypochloride for 1 minute and then rinsed with sterile distilled water to remove the traces of sodium hypochloride. These leaf bits are transferred to potato dextrose agar medium in petriplates and kept for incubation at $28 \pm 2^{\circ} \mathrm{C}$. When the growth of the fungus from the leaf bits was seen on the PDA surface, the hyphal bits from the periphery of the culture growing in the petriplates was transferred to the PDA in culture tubes. The culture was purified by hyphal tip method and pure culture was maintained on PDA by regular sub culturing at frequent intervals. Pathogen was also isolated from sclerotial bodies by keeping on Petri plate containing sterilized PDA after sterilizing with $70 \%$ ethanol followed by three washing in sterile distilled water. Plates were incubated at $28 \pm 2 \mathrm{C}$ and observed periodically for growth of the fungus. The culture was purified by single hyphal tip method and maintained on PDA by periodical transfer throughout the present investigation.

\section{Isolation of native antagonistic bacteria from rhizosphere}

Antagonistic bacteria were isolated by following serial dilution technique (Johnson and Curl, 1977). Composite soil sample was collected from rhizosphere of healthy plants. The soil was dried under shade and then used for serial dilution. To get $10^{-1}$ dilution, ten gram of this soil was dissolved in $90 \mathrm{ml}$ of sterile distilled water. From this one $\mathrm{ml}$ of soil suspension was taken and added to nine $\mathrm{ml}$ of sterile distilled water to get $10^{-2}$ dilution. This was repeated until a final dilution of $10^{-4}$ for isolation of fungi and $10^{-6}$ for bacteria. Antagonistic bacteria were isolated on King's $\mathrm{B}$ medium by using a dilution of $10^{-6}$. One $\mathrm{ml}$ of final dilution of soil suspension was poured into sterilized Petri plates, and then the melted and cooled media was poured. Plates were rotated gently on the laminar air flow bench to get uniform distribution of soil suspension in the medium. Then the plates were incubated at $28 \pm 2{ }^{\circ} \mathrm{C}$ and observed at frequent intervals for the development of colonies. Dual culture technique was used to identify the potential antagonistic isolate of Pseudomonas fluorescens. Isolates used in the present investigation are listed in Table 1.

\section{Fungal-Bacterial Interaction in Dual Culture}

Pathogen, $R$. solani was inoculated at the center of $9.0 \mathrm{~cm}$ diameter PDA plate. Test bacterial cultures were streaked individually on both the sides of the $R$. solani at $2.5 \mathrm{~cm}$ distance leaving $2.0 \mathrm{~cm}$ from periphery, Plates inoculated with $R$. solani alone were utilized as checks. Inoculated plates were incubated at 
$28 \pm 2{ }^{\circ} \mathrm{C}$ observations were recorded as zone of inhibition up to four days (when $R$. solani completely occupied the plate in monoculture check) (Lahlali et al., 2007 and Reddy et al., 2010).

Observations were recorded on mycelial growth of $R$. solani and per cent inhibition in $R$. solani growth was calculated using the following formula (Vincent et al., 1927).

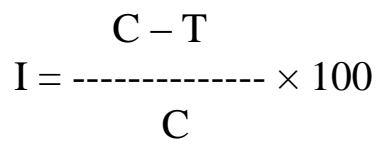

Where, $\mathrm{I}=$ Per cent reduction in growth of test pathogen, $\mathrm{C}=$ Radial growth $(\mathrm{cm})$ in control, $\mathrm{T}=$ Radial growth $(\mathrm{cm})$ in treatments.

Antagonistic effect of $\boldsymbol{P}$. fluorescens on the viability of the sclerotia of $R$. solani in vitro

The potential antagonistic $P$. fluorescens NB-3 isolate against $R$. solani was identified in the Experiment 3.9.2 and it was used for this experiment. The bacterial culture was grown on Kings B medium for $48 \mathrm{hr}$ and suspension was prepared and made serial dilutions from $10^{-4}$ to $10^{-8} \mathrm{CFU} / \mathrm{ml}$. Sclerotia were soaked in each dilution for different time periods of 10 , 20 and 30 minutes before transferring on to PDA for testing their viability (Bashar et al., 2010). Experimental design used was CRD and three replications were maintained per concentration of the isolate. Per cent inhibition of sclerotial germination was calculated.

Per cent inhibition

$\frac{\text { Total number of sclerotia- number of germinated sclerotia }}{\text { Total number of sclerotia }} \times 100$

Antagonistic effect of $\boldsymbol{P}$. fluorescens on the viability of the sclerotia of $R$. solani in soil

Dried paddy soil was used in this experiment. $10 \mathrm{~g}$ of soil was taken into plastic cups and ten sclerotia of $R$. solani was mixed with the soil.
This is a unit representing a replication of a concentration of bacterial suspension. The bacterial suspension of $P$. fluorescens from $10^{-}$ ${ }^{4}$ to $10^{-8} \mathrm{CFU} / \mathrm{ml}$ were added to the plastic cup containing sclerotia and soil mixture upto saturation and incubate for $10 \mathrm{~d}$. After $10 \mathrm{~d}$ the sclerotia were retrieved and placed on PDA medium for testing their viability. Experimental design used was CRD and three replications were maintained per concentration of the isolate. Per cent inhibition of sclerotial germination.

\section{Results and Discussion}

\section{Isolation of $\boldsymbol{R}$. solani}

The culture obtained on PDA at $28 \pm 1^{\circ} \mathrm{C}$ was light brown colour occupying $9 \mathrm{~cm}$ diameter Petriplate in 3 days of incubation. The pathogen produced dark brown, irregular, loose type of sclerotial bodies on PDA.

Effect of $P$. fluorescens on the mycelial growth of $R$. solani in vitro and identification of potential antagonistic isolate against $R$. solani

Three isolates of $P$. fluorescens were assessed for their antagonistic potential against $R$. solani. Bacterial isolates were screened based on their antagonistic potential against $R$. solani in vitro in dual culture. In control plates, i.e., in monoculture, $R$. solani grew to the extent of $4.5 \mathrm{~cm}$ radius covering the entire plate in two days. Variation existed in the growth of $R$. solani with different Pseudomonas isolates in dual culture (Table 2 ). The data was analysed using CRD and the results was presented here with.

Based on the mean inhibition \% observed in the growth of $R$. solani due to the presence of $P$. fluorescens in dual culture plates, the results obtained indicated that maximum inhibition was due to NLR-B3 (66.76\%) 
followed by NLR-B1 (63.32\%). Least mean inhibition was observed with NLR-B2 (57.30\%) (Fig.1).

Effect of $P$. fluorescens on the sclerotial viability of $R$. solani in vitro

The potential antagonistic $P$. fluorescens NLR-B-3 isolate against $R$. solani was identified during screening and it was used for this experiment. The bacterial culture was grown on Kings $\mathrm{B}$ medium for $48 \mathrm{~h}$ and suspension was prepared and made serial dilutions from $10^{-4}$ to $10^{-8} \mathrm{CFU} / \mathrm{ml}$.

Sclerotia were soaked in each dilution for different time periods of 10,20 and $30 \mathrm{~min}$, sclerotia were soaked in distilled water for control and sclerotia were transfered on to PDA for testing their viability. The results were presented in the Table 3 .
Among all the treatments, control showed 100 $\%$ sclerotial germination. Similarly at all the concentrations from $10^{-4}$ to $10^{-8} \mathrm{CFU} / \mathrm{ml}$ of bacterial suspension, there was no inhibition in sclerotial germination at 10 min incubation (Plate 3.3), whereas at 20 min incubation germination of sclerotia was inhibited. At $10^{-4}$ concentration inhibition was $73.33 \%$, at $10^{-5}$ concentration inhibition was $43.33 \%$, at $10^{-6}$ concentration inhibition was $30 \%$, no inhibition of sclerotial germination was observed.at $10^{-7}$ and $10^{-8}$ concentrations. At 30 min. incubation, inhibition in sclerotial germination was $53.33 \%$ at $10^{-4}$ concentration, $36.67 \%$ at $10^{-5}$ concentration, $30 \%$ at $10^{-6}$ concentration, $13.33 \%$ at $10^{-7}$ concentration and at $10^{-8}$ concentration 13.33 $\%$ inhibition was observed. Per cent inhibition increased with increase in concentration of bacterial suspension at 20 and $30 \mathrm{~min}$ incubation periods.

Table.1 Different $P$. fluorescens isolates tested

\begin{tabular}{|c|c|c|}
\hline Isolate & Isolated from & Designated as \\
\hline P. fluorescens & Rice rhizosphere & NLR-B1 \\
\hline P. fluorescens & Rice rhizosphere & NLR-B2 \\
\hline P. fluorescens & Rice rhizosphere & NLR-B3 \\
\hline
\end{tabular}

Table.2 In vitro efficacy of bacterial antagonists on the mycelial growth of Rhizoctonia solani

\begin{tabular}{|c|c|c|c|c|}
\hline S. No. & Isolate & Designated as & $\begin{array}{c}\text { Radial growth } \\
\text { in cm }\end{array}$ & $\begin{array}{c}\text { Per cent } \\
\text { Inhibition }\end{array}$ \\
\hline $\mathbf{1}$ & P. fluorescens & NLR-B1 & 1.65 & 63.32 \\
& & & & $(52.70)$ \\
\hline $\mathbf{2}$ & P. fluorescens & NLR-B2 & 1.92 & 57.30 \\
& & & & $(49.17)$ \\
\hline $\mathbf{3}$ & P. fluorescens & NLR-B3 & 1.50 & 66.76 \\
& & & 4.50 & 0.00 \\
\hline $\mathbf{4}$ & Control & & & $(0.00)$ \\
\hline & CD $(\mathrm{P}=0.01)$ & & & 0.35 \\
\hline & SEm \pm & & & 0.11 \\
\hline & SEd \pm & & & 0.16 \\
\hline & CV\% & & & 0.57 \\
\hline
\end{tabular}


Table.3 In vitro efficacy of bacterial antagonists on the sclerotial viability of Rhizoctonia solani

\begin{tabular}{|c|c|c|c|c|c|c|c|}
\hline \multirow[t]{2}{*}{ S. No } & \multirow{2}{*}{$\begin{array}{l}\text { Bacteria } \\
\text { isolate } \\
\text { NLR-B3, } \\
\text { CFU/ml }\end{array}$} & \multicolumn{3}{|c|}{ Per cent germination of sclerotia } & \multicolumn{3}{|c|}{ Per cent inhibition of Sclerotia } \\
\hline & & $10 \mathrm{~min}$ & $20 \mathrm{~min}$ & $30 \mathrm{~min}$ & $10 \mathrm{~min}$ & $20 \mathrm{~min}$ & $30 \mathrm{~min}$ \\
\hline 1 & $10^{-4}$ & 100.00 & $\begin{array}{c}26.67 \\
(30.98)\end{array}$ & $\begin{array}{c}46.67 \\
(43.06)\end{array}$ & 0.00 & $\begin{array}{c}73.33 \\
(58.98)^{* *}\end{array}$ & $\begin{array}{c}53.33 \\
(46.90)\end{array}$ \\
\hline 2 & $10^{-5}$ & 100.00 & $\begin{array}{c}56.67 \\
(48.83)\end{array}$ & $\begin{array}{c}63.33 \\
(52.75)\end{array}$ & 0.00 & $\begin{array}{c}43.33 \\
(41.13)\end{array}$ & $\begin{array}{c}36.66 \\
(37.21)\end{array}$ \\
\hline 3 & $10^{-6}$ & 100.00 & $\begin{array}{c}70.00 \\
(56.77)\end{array}$ & $\begin{array}{c}70.00 \\
(56.77)\end{array}$ & 0.00 & $\begin{array}{c}30.00 \\
(33.19)\end{array}$ & $\begin{array}{c}30.00 \\
(33.19)\end{array}$ \\
\hline 4 & $10^{-7}$ & 100.00 & $\begin{array}{c}93.33 \\
(81.14)\end{array}$ & $\begin{array}{c}86.67 \\
(68.83)\end{array}$ & 0.00 & $\begin{array}{c}6.66 \\
(8.85)\end{array}$ & $\begin{array}{c}13.33 \\
(21.13)\end{array}$ \\
\hline 5 & $10^{-8}$ & 100.00 & $\begin{array}{r}100.00 \\
(90.00)\end{array}$ & $\begin{array}{c}86.67 \\
(68.83)\end{array}$ & 0.00 & $\begin{array}{c}0.00 \\
(0.00)\end{array}$ & $\begin{array}{c}13.33 \\
(21.33)\end{array}$ \\
\hline 6 & Control & 100.00 & $\begin{array}{r}100.00 \\
(90.00)\end{array}$ & $\begin{array}{r}100.00 \\
(90.00)\end{array}$ & 0.00 & $\begin{array}{c}0.00 \\
(0.00)\end{array}$ & $\begin{array}{c}0.00 \\
(0.00)\end{array}$ \\
\hline & $\mathrm{CD}(\mathrm{P}=0.01)$ & & 11.87 & 6.02 & & 11.86 & 6.01 \\
\hline & SEm \pm & & 3.81 & 1.93 & & 3.80 & 1.93 \\
\hline & $\mathrm{SEd} \pm$ & & 5.39 & 2.73 & & 5.38 & 2.73 \\
\hline
\end{tabular}

** Figures in parentheses are angular transformed values.

Table.4 Evaluation of bacterial antagonists on the sclerotial viability of Rhizoctonia solani in soil

\begin{tabular}{|c|l|c|c|}
\hline S. No. & $\begin{array}{c}\text { Bacteria isolate NLR- } \\
\text { B3, CFU/ml }\end{array}$ & $\begin{array}{c}\text { Per cent germination of } \\
\text { sclerotia }\end{array}$ & $\begin{array}{c}\text { Per cent inhibition of } \\
\text { Sclerotia }\end{array}$ \\
\hline $\mathbf{1}$ & $10^{-4}$ & 43.33 & 56.66 \\
& & $(41.14)$ & $(48.82)^{* *}$ \\
\hline $\mathbf{2}$ & $10^{-5}$ & 63.33 & 36.66 \\
& & $(52.75)$ & $(37.21)$ \\
\hline $\mathbf{3}$ & $10^{-6}$ & 83.33 & 16.66 \\
& & $(66.12)$ & $(23.84)$ \\
\hline $\mathbf{4}$ & $10^{-7}$ & 100.00 & 0.00 \\
& & $(90.00)$ & $(0.00)$ \\
\hline $\mathbf{5}$ & $10^{-8}$ & 100.00 & 0.00 \\
& & $(90.00)$ & $0.00)$ \\
\hline $\mathbf{6}$ & Control & 100.00 & 0.00 \\
& & $(90.00)$ & $(0.00)$ \\
\hline & CD $(\mathrm{P}=0.01)$ & 4.94 & 4.93 \\
\hline & SEm \pm & 1.58 & 1.58 \\
\hline & SEd \pm & 2.24 & 2.24 \\
\hline & CV\% & 3.83 & 14.0 \\
\hline
\end{tabular}

** Figures in parentheses are angular transformed values. 


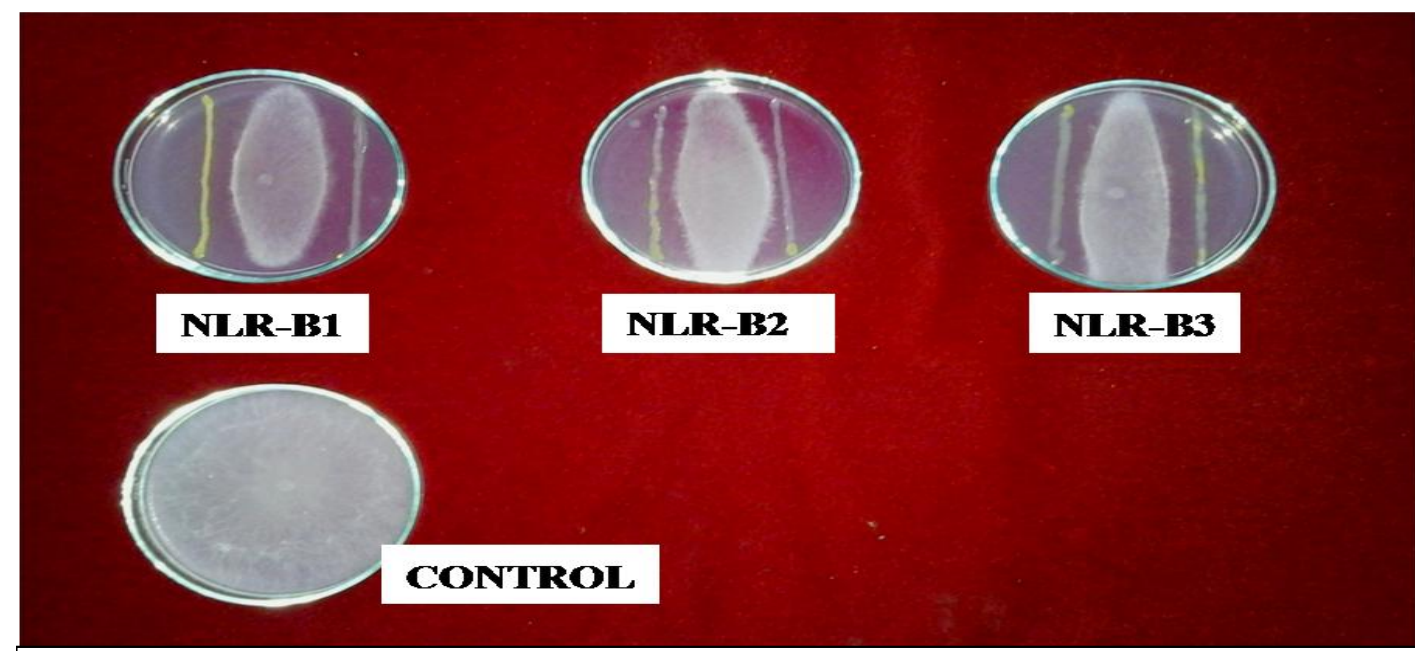

Fig.1 : In vitro efficacy of $P$. fluorescens isolates on mycelial growth of $R$. solani in dual culture

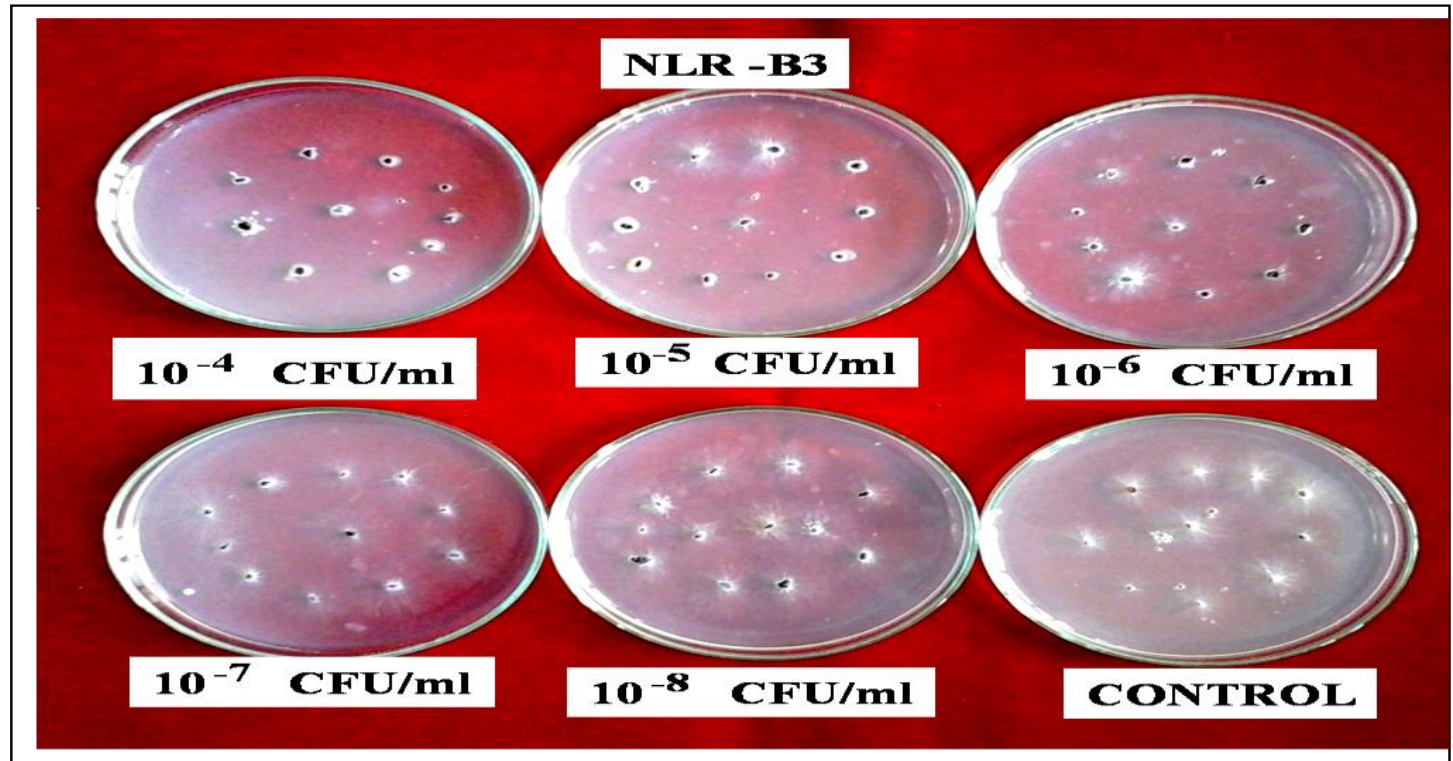

Fig.2: Efficacy of soil application of $\boldsymbol{P}$.fluorescens isolates on sclerotiial viability of of $\boldsymbol{R}$. solani at $10 \mathrm{~d}$ incubation

Per cent inhibition of sclerotial germination was recorded in the following order.

$10^{-4}>10^{-5}>10^{-6}>10^{-7}>10^{-8} \mathrm{CFU} / \mathrm{ml}$.

Effect of $\boldsymbol{P}$. fluorescens on the sclerotial viability of $R$. solani in soil

Dried paddy soil was used in this experiment.
$10 \mathrm{~g}$ of soil was taken into plastic cups and ten sclerotia of $R$. solani was mixed with the soil. This is a unit representing a replication of a concentration of bacterial suspension.

The bacterial suspension of $P$. fluorescens from $10^{-4}$ to $10^{-8} \mathrm{CFU} / \mathrm{ml}$ were added to the plastic cups containing sclerotia and soil mixture upto saturation and incubated for 10 
d. After $10 \mathrm{~d}$ the sclerotia were retrieved and placed on PDA medium for testing their viability. The results were presented in the Table 4.

Among all the treatments, the control showed no inhibition whereas the inhibition was 56.67 $\%$ at $10^{-4}$ concentration, 36.66 per cent at $10^{-5}$ concentration and $16.66 \%$ at $10^{-6}$ concentration However at lower concentration $10^{-7}$ and $10^{-8}$ all sclerotia were germinated i.e., no inhibition was observed. With increase in concentration of the bacterial suspension the per cent inhibition was also increased significantly in all the treatments (Fig. 2).

Vasantha Devi et al., (1989) reported inhibition in sclerotial germination declined with prolonged incubation periods with bacteria.

In dual culture, among the three isolates of Pseudomonas fluorescens, NLR-B1, NLR-B2 and NLR-B3, the isolate NLR-B3 was found to be antagonistic to $R$. solani showing the $66.76 \%$ inhibition of mycelial growth of $R$. solani. There was no inhibition in sclerotial germination at $10 \mathrm{~min}$ incubation at all concentrations of bacterial suspension, whereas at $20 \mathrm{~min}$ incubation, inhibition of sclerotial germination was 73.33 per cent at $10^{-4}$ concentration, 43.33 per cent at $10^{-5}$ concentration, 30 per cent at $10^{-6}$ concentration and there was no inhibition of sclerotial germination at $10^{-7}$ and $10^{-8}$ concentrations. At the incubation period of 30 min. inhibition in sclerotial germination was 53.33 per cent at $10^{-4}$ concentration, 36.67 per cent at $10^{-5}$ conc., 30 per cent at $10^{-6}$ concentration. Similar inhibition of 13.33 per cent was observed both at $10^{-7}$ and at $10^{-8}$ concentration. When the bacterial suspensions at the earlier concentrations were added to the soil and incubated for 10 days, the inhibition of sclerotial germination was 56.67 per cent at $10^{-4}$ concentration, 36.66 per cent at $10^{-5}$ concentration and 16.66 per cent at $10^{-6}$ concentration. However at lower concentration of $10^{-7}$ and $10^{-8}$ there was no inhibition of sclerotial germination. There was a significant increase in per cent inhibition of sclerotial germination with increase in concentration of the bacterial suspension. Hence, the bacterial antagonist (P. fluorescens) found effective against $R$. solani.

\section{Acknowledgements}

Financial support received from Acharya N.G. Ranga Agricultural University, Andhra Pradesh is great fully acknowledged. This work is part of thesis submitted in ANGRAU.

\section{References}

Bashar, M.A., Hossain, M.A., Rahman M.M., Uddin, M.N and Begum, M.N. 2010. Biological control of sheath blight disease of rice by using antagonistic bacteria. Bangladesh Journal of Scientific and Industrial Research. 45(3): 225-232.

Lahlali, R., Baji, M and Jijakli, M.H. 2007. Isolation and Evaluation of Bacteria and Fungi as Biological control Agents against Rhizoctonia solani. Communications in Agricultural and Applied Biological Sciences. 72(4): 973-982.

Lee, F.N and Rush, M.C. 1983. Rice Sheath Blight: A major Rice Disease. Plant Disease. 67(7): 829-832.

Ou, S.H. 1985. Rice Diseases. CAB International, Leutralsales, Fanham Royals Slough, UK: 272-285.

Reddy, P.B., Jansi rani, Reddy, M.S and Vijay Krishna Kumar. K. 2010. Isolation of siderophore- producing strains of rhizobacterial fluorescent pseudomonads and their biocontrol against rice fungal pathogens. 
International Journal of Applied Biology and Pharmaceutical Technology.1: 133-137.

Vasantha Devi, T., Malar Vizhi, R., Sakthivel, N. and Gnanamanickam, S.S. 1989. Biological control of sheath blight of rice in India with antagonistic bacteria. Plant and Soil. 119: 325-330.

Vincent, J. M. 1927. Distortion of fungal hyphae in presence of certain inhibitors. Nature 159: 850.

\section{How to cite this article:}

Sandhya Y., C. P. D. Rajan and Reddikumar M. 2018. Antagonistic Effect of Pseudomonas fluorescens on the Mycelial Growth and the Viability of the Sclerotia of Rhizoctonia solani in vitro and in Soil. Int.J.Curr.Microbiol.App.Sci. 7(06): 3038-3045.

doi: https://doi.org/10.20546/ijcmas.2018.706.357 